\title{
UPAYA MENINGKATKAN HASIL BELAJAR IPA MENGGUNAKAN MODEL PEMBELAJARAN DIRECT INSTRUCTION (DI) BERBANTUAN MEDIA AUDIO VISUAL PADA PESERTA DIDIK
}

\author{
oleh \\ Cancie $^{1}$, Ade S. Permadi ${ }^{2}$ \\ Email: adepermadi87@gmail.com
}

\begin{abstract}
This research aims to improve learning outcomes of science and describe learning activities of students by using Direct Instruction learning models assisted by Audio Visual media on students. The research method used in this study was classroom action research (PTK). The research subjects were 27 grade SDN 3 Panarung students. The technique of collecting data uses observation and tests. The results of the study show that the learning activities of students become good. Teacher activities in the first cycle averaged 2.4 categories quite well and the second cycle averaged 3.5 good categories, while the activities of students in the first cycle averaged 2.6 categories enough and the second cycle averaged 3.1 categories well. There is an increase in science learning outcomes using the Direct Instraction (DI) learning model assisted by Audio Visual media in fourth grade students of SDN-3 Panarung Palangka Raya 2016/2017 school year with the results of analysis on the Pratindakan classical completeness which is $40.7 \%$ with an average value 65 , the first cycle of classical completeness is $74 \%$ with an average value of 72 , and classical completeness in cycle II is $100 \%$ with an average value of 87.5
\end{abstract}

(C) Muhammadiyah University Palangkaraya

Keywords: Science Learning Outcomes, Direct Instruction Learning Model, AudioVisual Media.

\begin{abstract}
ABSTRAK
Penelitianini bertujuan untuk meningkatkan hasil belajar IPA dan mendeskripsikan aktivitas belajar peserta didik dengan menggunakan model pembelajaran Direct Instruction berbantuan media Audio Visual pada peserta didik. Metode penelitian yang digunakan dalam penelitian ini adalah penelitian tindakan kelas (PTK).Subjek penelitian adalah kelas IV SDN 3 Panarung sebanyak 27orang peserta didik. Teknik pengumpulan data menggunakan observasi dan tes. Hasil penelitian menunjukan bahwa Aktivitas belajar peserta didik menjadi baik. Aktivitas guru pada siklus I rata-rata 2,4 kategori cukup baik dan siklus II rata-rata 3,5 kategori baik, sedangkan aktivitas peserta didik siklus I rata-rata 2,6 kategori cukup dan siklus II ratarata 3,1 kategori baik. Terdapat peningkatan hasil belajar IPA menggunakan model pembelajaran Direct Instraction(DI) berbantuan media Audio Visual pada peserta didik kelas IV SDN-3 Panarung Palangka Raya tahun pelajaran 2016/2017 dengan hasil analisis pada Pratindakan ketuntasan klasikal yaitu 40,7 \% dengan nilai rata-rata 65, siklus I ketuntasan klasikal yaitu $74 \%$ dengan nilai rata-rata 72 , dan ketuntasan klasikal siklus II $100 \%$ dengan nilai rata-rata 87,5 .
\end{abstract}

(c) Universitas Muhammadiyah Palangkaraya

Kata Kunci: Hasil Belajar IPA, Model Pembelajaran Direct Instruction, Media AudioVisual. 


\section{PENDAHULUAN}

Pendidikan memegang peranan yang sangat penting dan strategis dalam menciptakan kualitas sumber daya manusia. Berbagai usaha telah dilakukan untuk meningkatkan mutu pendidikan nasional, antara lain melalui pelatihan dan peningkatan kualitas guru, penyempurnaan kurikulum, pengadaan buku dan alat pelajaran, perbaikan sarana dan prasarana pendidikan, dan peningkatan mutu manajemen sekolah. Namun, berbagai indikator mutu pendidikan tersebut belum menunjukkan peningkatan yang memadai. Berlakunya Kurikulum Tingkat Satuan Pendidikan (KTSP) sekarang ini, sangat menuntut perubahan paradigma dalam pendidikan dan pengajaran, khususnya pada jenis dan jenjang pendidikan formal. Perubahan tersebut harus pula diikuti oleh guru yang bertanggung jawab atas penyelenggaraan pembelajaran di sekolah (di dalam kelas ataupun di luar kelas).

Menurut Komarudin (dalam Trianto, 2007:2) menyatakan bahwa "salah satu perubahan paradigma pembelajaran tersebut adalah orientasi pembelajaran yang semula berpusat pada guru (teacher centered) beralih berpusat pada siswa (student centered). Semua perubahan tersebut dimaksudkan untuk memperbaiki mutu pendidikan, baik dari segi proses maupun hasil pendidikan". Namun, strategi yang selama ini digunakan oleh guru dalam pembelajaran adalah metode ceramah, metode tanya jawab, metode penugasan, dan metode ekspositori sehingga guru lebih banyak mendominasi proses pembelajaran dengan memberikan informasi kepada peserta didik, tanpa memberikan peserta didik tersebut untuk mencari sendiri konsep yang akan dipelajarinya. KTSP sekarang ini, juga menghendaki bahwa suatu pembelajaran pada dasarnya tidak hanya mempelajari tentang konsep, teori, dan fakta, tetapi juga aplikasi dalam kehidupan sehari-hari. Dengan demikian, materi pembelajaran tidak hanya tersusun atas hal-hal sederhana yang bersifat hapalan dan pemahaman, tetapi juga tersusun atas materi yang kompleks yang memerlukan analisis, aplikasi, dan sintesis. Untuk itu, guru harus dapat menciptakan situasi dan kondisi kelas yang kondusif agar proses belajar mengajar dapat berlangsung sesuai dengan tujuan yang diharapkan.

Undang-Undang

Sistem

Pendidikan Nasional No. 20 Tahun 2003 Pasal 37 Ayat (1) Kurikulum pendidikan dasar dan menengah salah satunya wajib memuat ilmu pengetahuan alam. Sesuai dengan Undang-Undang tersebut, maka mata pelajaran Ilmu Pengetahuan Alam wajib diberikan pada siswa-siswa pada jenjang pendidikan dasar dan menengah. Pada jenjang pendidikan dasar dan menengah mata pelajaran IPA harus mencakup beberapa standar kompetensi dan kompetensi dasar. Standar kompetensi dan kompetensi dasar dalam mata pelajaran IPA tersebut tertuang dalam standar isi.

Peraturan Menteri Pendidikan Nasional Nomor 22 Tahun 2006 tentang 
standar isi untuk satuan pendidikan dasar dan menengah bahwa standar kompetensi IPA merupakan standar minimum yang secara nasional harus dicapai oleh peserta didik dan menjadi acuan dalam pengembangan kurikulum di setiap satuan pendidikan. Pencapaian SK dan KD didasarkan pada pemberdayaan peserta didik untuk membangun kemampuan, bekerja ilmiah, dan pengetahuan sendiri yang difasilitasi oleh guru. Penerapan IPA perlu dilakukan secara bijaksana agar tidak berdampak buruk terhadap lingkungan. IPA diperlukan dalam kehidupan sehari-hari untuk memenuhi kebutuhan manusia melalui pemecahan masalah-masalah yang dapat diidentifikasi. Oleh karena itu pembelajaran IPA di SD/MI menekankan pada pemberian pengalaman belajar secara langsung melalui penggunaan dan pengembangan keterampilan proses dan sikap ilmiah.

Mata pelajaran IPA merupakan salah satu dari sejumlah mata pelajaran yang diajarkan di Sekolah Dasar sesuai dengan kurikulum pendidikan dasar. Ilmu Pengetahuan Alam (IPA) berkaitan dengan cara mencari tahu tentang alam secara sistematis, sehingga IPA bukan hanya penguasaan kumpulan pengetahuan yang berupa fakta-fakta, konsep-konsep atau prinsip-prinsip saja tetapi juga merupakan suatu proses penemuan. Oleh karena itu, pendidikan IPA diharapkan dapat menjadi wahana bagi peserta didik untuk mempelajari diri sendiri dan alam sekitar (Trianto, 2007).

Selama ini pembelajaran IPA di sekolah dasar masih banyak mengalami hambatan yang menjadi problematika dalam pendidikan IPA. Salah satunya adalah proses pembelajaran yang diberikan di kelas pada umumnya hanya mengemukakan konsep-konsep dalam suatu materi. Hal ini nampak pada rerata hasil belajar peserta didik yang senantiasa masih sangat memprihatinkan. Prestasi ini merupakan hasil kondisi pembelajaran yang masih bersifat konvensional dan tidak menyentuh ranah siswa itu sendiri, yaitu bagaimana sebenarnya belajar itu. Dengan kata lain, bahwa proses pembelajaran masih memberikan dominasi guru dan tidak memberikan akses bagi siswa untuk berkembang secara mandiri melalui penemuan dan proses berpikirnya. Kondisi seperti itu tidak akan meningkatkan kemampuan siswa dalam memahami pelajaran IPA. Memperhatikan permasalahan di atas sudah selayaknya seorang guru dalam pembelajaran IPA melakukan sebuah inovasi untuk meningkatkan kualitas mutu pendidikan yang secara khusus memerlukan perubahan pola pikir positif yang digunakan sebagai landasan pelaksanaan kurikulum.

Kenyataan di atas diperkuat oleh hasil observasi yang dilakukan di SDN3 Panarung Palangka Raya pada kelas IV terdapat beberapa kendala dalam proses pembelajaran IPA, yaitu dalam pelaksanaan pembelajaran IPA guru hanya fokus pada pengembangan materi yang ada pada buku sehingga konsentrasi peserta didik ketika mengikuti proses pembelajaran tidak bertahan lama. Hasil belajar IPA peserta didik masih di bawah Kriteria Ketuntasan Minimal (KKM) yang 
ditetapkan di SDN-3 Panarung Palangka Raya yaitu 65. Rata-rata hasil belajar IPA kelas IV adalah 62 dengan jumlah peserta didik sebanyak 27 orang. Dari hasil observasi juga ditemukan beberapa faktor yang dapat dikelompokkan menjadi empat, yaitu: (1) pemilihan model pembelajaran yang kurang sesuai, menjadi kendala dalam mencapai tujuan yang telah dirumuskan. Dalam menggunakan model pembelajaran saat proses pembelajaran, hendaknya bukan hanya guru saja yang aktif dalam proses pembelajaran, melainkan diharapkan terjadinya interaksi antara guru dan peserta didik serta peserta didik dengan peserta didik. (2) Pengetahuan awal peserta didik yang belum terarahkan dengan baik dalam pembelajaran. Pemanfaatan media yang jarang digunakan sebagai sumber belajar. Guru dalam mengajar lebih banyak berpatokan pada buku ajar dan jarang memperhatikan media yang ada di sekitar peserta didik yang dapat digunakan sebagai sumber belajar. (4) Bentuk dan cara penilaian perolehan belajar yang digunakan kurang sesuai dengan tujuan pembelajaran.

Upaya peningkatan mutu pendidikan sangat dipengaruhi oleh faktor guru, peserta didik, sarana belajar, situasi belajar bahkan metode dan model yang digunakan. Guru diharapkan dapat menyiapkan pembelajaran dengan penyampaian yang baik dan tepat, sehingga peserta didik lebih mudah membangun pengetahuan yang diajarkan. Hal ini menunjukkan bahwa model pembelajaran berpengaruh pada hasil belajar peserta didik. Penerapan model pembelajaran inovatif yang sesuai dengan karakteristik materi dan siswa diduga dapat membantu peserta didik dalam pencapaian hasil belajar. Perlu diterapkan suatu perspektif model pembelajaran yang inovatif, salah satunya adalah model pembelajaran Direct Instruction (DI).

Salah satu model pembelajaran yang inovatif adalah model Direct Instruction (Pengajaran Langsung). Model Direct Instruction (DI) merupakan salah satu model pembelajaran yang dimaksudkan untuk membantu siswa mempelajari berbagai keterampilan dan pengetahuan dasar yang diajarkan secara tahap demi tahap. Pengajaran langsung dirancang untuk meningkatkan penguasaan berbagai keterampilan pengetahuan deklaratif dan pengetahuan prosedural yang dapat diajarkan secara tahap demi tahap (Arends 2008: 294-295). Kelebihan dari Model Direct Instruction (DI) pembelajarannya dirancang secara spesifik untuk meningkatkan pengetahuan faktual yang diajarkan secara tahap demi tahap dengan tujuan untuk membantu siswa menguasai pengetahuan prosedural yang dibutuhkan untuk melakukan berbagai keterampilan kompleks.

Media pembelajaran juga berperan dalam mengoptimalkan proses pembelajaran. Penggunaan media pembelajaran dapat menciptakan pembelajaran yang menarik dan memudahkan siswa memahami materi yang disampaikan. Media yang dapat digunakan dalam pembelajaran sangat beragam. Hal tersebut disebabkan 
karena media memungkinkan adanya interaksi langsung antara siswa dengan apa yang dipelajari. Dengan menggunakan media akan memberikan rangsangan yang sangat penting bagi siswa untuk mempelajari berbagai hal terutama menyangkut pengembangan keterampilan tertentu (Ibrahim, 2003). Dengan demikian dapat dinyatakan bahwa model Direct Instruction (Pengajaran Langsung) berbantuan media Audio Visual dapat memberikan pengaruh yang positif terhadap hasil belajar peserta didik, karena dalam media ini peserta didik dapat melihat gambar dan suara sehingga dapat menjalin interaksi yang baik antara guru dengan peserta didik. Media Audiovisual, yaitu jenis media yang selain mengandung unsur suara juga mengandung unsur gambar yang bisa dilihat, misalnya rekaman video, berbagai ukuran film, slide suara, dan lain sebagainya (Jennah, 2009:56).

Adapun kelebihan dari media audio visual yaitu: (1) Media audio visual bisa berperan dalam pembelajaran tutorial; (2) Memperjelas penyajian pesan agar tidak terlalu bersifat verbalistis (dalam bentuk katakata, tertulis atau lisan belaka); (3) Mengatasi perbatasan ruang, waktu dan daya indera.

Berdasarkan uraian permasalahan tersebut, kualitas pembelajaran IPA perlu ditingkatkan terutama dalam proses dan hasil. Untuk itu diangkat masalah ini melalui suatu penelitian yang berjudul "Meningkatkan Hasil Belajar IPA Menggunakan Model Pembelajaran Direct Instruction (DI) Berbantuan Media Audio Visual Pada
Peserta Didik Kelas IV SDN-3 Panarung Palangka Raya Tahun Pelajaran 2016/2017”.

\section{METODE PENELITIAN}

Menurut Mulyasa (2011:4) mengemukakan bahwa penelitian tindakan kelas adalah "penelitian yang mengangkat masalah-masalah yang aktual yang dilakukan oleh para guru yang merupakan pencermatan kegiatan belajar yang berupa tindakan untuk memperbaiki dan meningkatkan praktik pembelajaran di kelas secara lebih profesional".

Jenis penelitian ini adalah Penelitian Tindakan Kelas (PTK), karena penelitian ini merupakan suatu pencermatan terhadap kegiatan berupa sebuah tindakan kelas, yang sengaja dimunculkan dan terjadi di dalam sebuah kelas.

Berdasarkan pendapat di atas, dapat disimpulkan penelitian tindakan kelas atau PTK adalah suatu peranan yang sangat penting dan strategis untuk meningkatkan mutu di berbagai aspek pembelajaran.

Dalam penelitian ini subjek penelitian adalah seluruh peserta didik kelas IV SDN-3 panarung Palangka Raya.

\section{HASIL DAN PEMBAHASAN}

Aktivitas belajar peserta didik menjadi baik dengan menggunakan model pembelajaran Direct Instraction(DI) berbantuan media Audio Visual dalam pembelajaran IPA pada peserta didik kelas IV SDN-3 Panarung Palangka Raya tahun pelajaran 2016/2017, terlihat dari 
aktivitas guru pada siklus I rata-rata 2,4 kategori cukup baik dan siklus II ratarata 3,5 kategori baik, sedangkan aktivitas peserta didik siklus I rata-rata 2,6 kategori cukup dan siklus II ratarata 3,1 kategori baik. Pada aktivitas belajar peserta didik setelah menggunakan model pembelajaran yang berbantuan media Audio Visual membuat aktif proses pembelajaran. Peserta didik terlihat fokus mendengarkan guru menjelaskan materi pembelajaran berbantuan video tentang kenampakan benda-benda langit.

Berikut ini adalah grafik yang menunjukkan persentase aktivitas guru dan peserta didik selama proses pembelajaran IPA pada saat pelaksanaan tindakan siklus I dan siklus II.

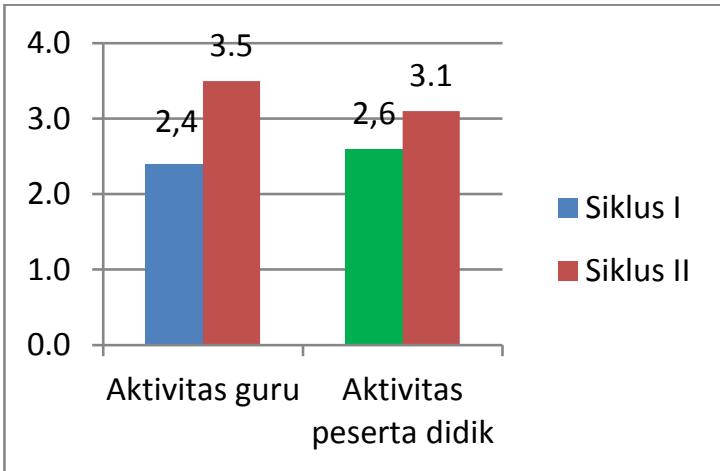

Gambar 1

Aktivitas Guru dan Peserta Didik

Terdapat peningkatan hasil belajar IPA menggunakan model pembelajaran Direct Instraction (DI) berbantuan media Audio Visual pada peserta didik kelas IV SDN-3 Panarung Palangka Raya tahun pelajaran 2016/2017. Berdasarkan hasil analisis peneliti diperoleh data bahwa pada Pra tindakan ketuntasan klasikal yaitu 40,7 \% dengan nilai rata-rata 64,7 , sedangkan di siklus
I ketuntasan klasikal yaitu $74 \%$ dengan nilai rata-rata 72 dan ketuntasan klasikal di Siklus II diperoleh data ketuntasan belajar peserta didik secara klasikal siklus II yaitu $100 \%$ dengan nilai ratarata 87,5 . Hasil belajar IPA pada materi kenampakan benda-benda langit dengan menggunakan model Direct Instraction (DI) berbantuan media audio visual terbukti meningkatkan hasil belajar IPA. Peserta didik lebih mudah memahami materi, memberi motivasi belajar, dan pembelajaran menjadi lebih menyenangkan.

Ketuntasan hasil belajar IPA pada pra tindakan, siklus I, siklus II dapat disajikan pada grafik di bawah ini :

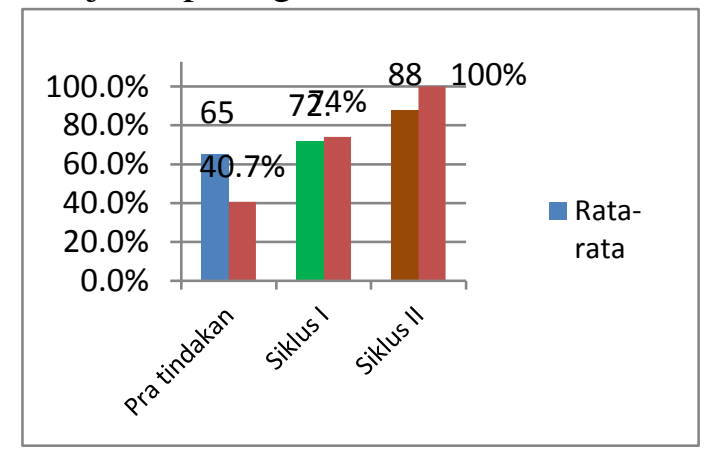

\section{Gambar 2}

Ketuntasan Hasil Belajar IPA

Pra Tindakan, Siklus I, Siklus II

\section{KESIMPULAN}

Aktivitas belajar peserta didik menjadi baikdengan menggunakan model pembelajaran Direct Instraction (DI) berbantuan media Audio Visual dalam pembelajaran IPA pada peserta didik kelas IVSDN-3 Panarung Palangka Raya tahun pelajaran 2016/2017, terlihat aktivitas guru pada siklus I rata-rata 2,4 kategori cukup baik dan siklus II rata-rata 3,5 kategori baik, sedangkan aktivitas peserta didik siklus 
I rata-rata 2,6 kategori cukup dan siklus

II rata-rata 3,1 kategori baik.

Terdapat peningkatan hasil belajar IPA menggunakan model pembelajaran Direct Instraction (DI) berbantuan media Audio Visual pada peserta didik kelas IVSDN-3 Panarung Palangka Raya tahun pelajaran 2016/2017 dengan hasil analisis padaPra tindakan ketuntasan klasikal yaitu 40,7 \% dengan nilai rata-rata 65 siklus I ketuntasan klasikal yaitu $74 \%$ dengan nilai ratarata 72, dan ketuntasan klasikal siklus II $100 \%$ dengan nilai rata-rata 88 .

\section{DAFTAR PUSTAKA}

\section{Depdiknas. 2004.}

Perpustakaan Perguruan Tinggi: Buku Pedoman, edisi ketiga. Jakarta: Depdiknas.

Depdiknas.2008. Kompetensi Evaluasi Pendidikan: Kriteria dan
Indikator. Keberhasilan

Pembelajaran. Diakses: Desember 2016.

Gafur, Abdul, 2012. Desain Pembelajaran, Konsep, Model, dan Aplikasinya dalam Perencanaan Pelaksanaan Pembelajaran. Yogyakarta: Ombak.

Gusmayani, Indri. 2012. Model Desain Pembelajaran. Bandung: Alfabeta Jannah, Rodhatul. 2009. Metode Penelitian Kuantitatif. Jakarta:PT Raja Grafindo Persada

Media Pembelajaran. Banjarmasin: Antasari Press.

Mulyasa, E. 2011. Standar Kompetensi dan Sertifikasi Guru. Bandung : Rosda.

Trianto. 2007.Model-model Pembelajaran Inovatif Berorientasi Konstruktivistik. Jakarta : Prestasi 